\title{
EDUKASI KESEHATAN REPRODUKSI REMAJA PUTRI TENTANG PERSONAL HYGIENE SAAT MENSTRUASI
}

\author{
Diyana Faricha Hanum ${ }^{1}$ Noviatul Rochma ${ }^{2}$, MahcicaAfshokun Nabila ${ }^{3}$ \\ Prodi Kebidanan Fakultas Kesehatan \\ Universitas Muhammadiyah Gresik Jl. Proklamasi No.54 Gresik \\ e-mail correspondence*:diyanafarichahanum99@umg.ac.id
}

\begin{abstract}
Naskah di terima $: 26 / 03 / 21$
Naskah di revisi : :08/06/21

Naskah di setujui : 05/07/21
\end{abstract}

\begin{abstract}
Abstrak
Kesehatan reproduksi remaja adalah suatu kondisi sehat yang menyangkut sistem, fungsi dan proses reproduksi yang dimiliki oleh remaja. Pentingnya menjaga kesehatan reproduksi bagi remaja karena masa remaja adalah waktu terbaik untuk membangun kebiasaan baik menjaga kebersihan, yang bisa menjadi aset dalam jangka panjang. Kegiatan pengabdian masyarakat telah dilakukan di SMK Dharma Wanita Kabupaten Gresik. Pengabdian Masyarakat dibagi menjadi beberapa tahap, yakni : penunjukan kader kesehatan reproduksi dari pihak sekolah dan p.enyuluhan Edukasi kesehatan reproduksi Remaja Putri tentang Personal Hygiene Saat Mentruasi melalui video yang diunggah di chanel youtube https://youtu.be/FZuNTxH8GrQ. Dilanjutkan dengan tanya jawab memakai media whatsapp (WA). Pengabdian masyarakat ini, diikuti oleh 10 siswa yang telah ditunjuk sebagai kader kesehatan reproduksi. Dan youtube kami diikuti oleh viewers 103 orang, 32 like dan subcriber yang berjumlah 18 orang. Pada akhir kegiatan pengabdian masyarakat ini, dengan harapan dapat membuat siswa remaja putri dapat menjadi teman konseling tentang kesehatan reprodukis remaja dengan teman sebaya dan dapat mencegah masalah yang mungkin timbul yang disebabkan oleh kurang tepatnya personal hygiene saat menstruasi, sehingga aktifitas belajar mengajar berjalan dengan baik dan ada peningkatan prestasi untuk siswa. Dan harapan kami sebagai tenaga kesehatan adalah remaja putri bisa bertanggung jawab atas kesehatan reproduksinya yang akan berdampak akan masa depannya sebagai wanita dan seorang ibu yang sehat.
\end{abstract}

Kata Kunci: Kesehatan Reproduksi, Remaja Putri, Personal Hygine, Menstruasi

\begin{abstract}
Adolescent reproductive health is a healthy condition that concerns the reproductive systems, functions and processes of adolescents. The importance of maintaining reproductive health for adolescents because adolescence is the best time to build good habits of maintaining hygiene, which can be an asset in the long term. Community service activities have been carried out at SMK Dharma Wanita, Gresik. Community Service is divided into several stages, namely: appointment of reproductive health cadres from the school and counseling on reproductive health education for female adolescents about personal hygiene during menstruation through videos uploaded on the youtube channel https://youtu.be/FZuNTxH8GrQ. Followed by questions and answers using the WhatsApp (WA) media. This community service was attended by 10 students who had been appointed as reproductive
\end{abstract}


Diyana F.-Edukasi Kesehatan Reproduksi Remaja Putri Tentang Personal Hygiene Saat Menstruasi -hlm 15-20

health cadres. And our YouTube is followed by 103 viewers, 32 likes and 18 subscribers. At the end of this community service activity, the hope is that it can make female adolescents students become counseling friends about adolescent reproductive health with peers and can prevent problems that may arise due to inaccurate personal hygiene during menstruation, so that teaching and learning activities run well and there is an increase in achievement for students. And our hope as health workers is that young women can be responsible for their reproductive health which will have an impact on their future as healthy women and mothers.

\section{Keywords: Reproductive health, female adolescents, personal hygiene, Menstruation}

\section{PENDAHULUAN}

Menurut WHO dalam Anugrahadi, yang disebut remaja adalah mereka yang berada pada tahap transisi antara masa kanak-kanak dan dewasa. Batasan usia remaja menurut WHO adalah 12 sampai 24 tahun. [1]. Menurut BKKBN (2013) remaja mengalami pertumbuhan dan perkembangan pesat pada aspek fisik, psikologis dan jugai ntelektual [2]. Remaja akan melalui banyak peristiwa dalam tahap perkembangan dan pertumbuhan, dan pada remaja putri akan mengalami perubahan salah satunya adalah peristiwa menstruasi.

Menstruasi adalah keluarnya darah dari dalam uterus, yang di akibatkan oleh terlepasnya lapisan dinding rahim disertai pelepasan endometrium dan terjadi setiap bulan [3]. Remaja putri rentan terkena infeksi organ reproduksi hal ini terjadi karena kurangnnya prilaku dalam merawat kebersihan diri terutama saat mengalami menstruasi. Angka insiden penyakit infeksi yang terjadi pada saluran reproduksi remaja (10 sampai 18 tahun) yaitu 35\% sampai $42 \%$. Penyebab dari infeksi saluran reproduksi salah satunya adalah prilaku personal hygiene yang tidakbenar. Prilaku tersebut meliputi; mengganti pembalut kurang dari empat kali sehari, bahan pembalut yang digunakan tidak tepat, sering menggunakan antiseptic, tidak mengganti celana dalam kurang dari dua kali sehari, dan caracebok yang salah sesudah BAK/ BAB [2].

Menurut Phytagoras (2017) bahwa perilaku remaja putri tentang personal hygiene saat menstruasi dalam komponen kognitif berkriteria baik adalah 47 persen, komponen afektif berkriteria baik sebanyak 26 persen, dan komponen konatif berkategori kurang sejumlah 27 persen.

Dengan makin banyaknya persoalan kesehatan reproduksi remaja, terutama yang berkaitan dengan personal hygiene, maka pemberian informasi, layanan dan pendidikan kesehatan pada remaja menjadi sangat penting [4]

Kesehatan reproduksi merupakan keadaan sehat fisik, mental, dan sosial secara utuh, tidak hanya bebas dari penyakit atau kecacatan yang berkaitan dengan sistem, fungsi, dan proses reproduksi. Maka dari itu salah satu upaya yang dapat di lakukan oleh petugas kesehatan dalam memberi dan atau meningkatankan pengetahuan masyarakat tentang kesehatan reproduksi dan permasalahannya adalah dengan cara memberikan pendidikan kesehatan [5].

Dan hal tersebut relevan juga dengan hasil kegiatan yang dilakukan oleh Wismaningsih (2017) menunjukkan bahwa persentase siswi yang mempunyai pengetahuan yang baik tentang higiene menstruasi setelah pelaksanaan promosi kesehatan adalah sebesar $80,6 \%$. Hal ini menunjukkan bahwa promosi kesehatan dapat meningkatkan pengetahuan remaja dalam memahami higiene menstruasi yang baik sebagai upaya meningkatkan kesehatan reproduksi pada remaja serta dapat diaplikasikan dalam kehidupan sehari-hari [6].

Kesehatan Reproduksi Remaja (KRR) merupakan bagian terpadu dari program kesehatan dan keluarga berencana di Indonesia. Program terpadu ini secara khusus bertujuan untuk mengatasi masalah terkait pernikahan dini, kehamilan tidak diinginkan, konsumsi tembakau dan alkohol, serta HIV-AIDS [7].

Menurut Adjie (2013), remaja perlu mengetahui kesehatan reproduksi agar memiliki informasi yang benar mengenai proses reproduksi serta berbagai faktor yang berhubungan. Dengan informasi yang benar, diharapkan remaja memiliki sikap dan tingkah laku yang bertanggung jawab mengenai proses reproduksi [8].

SMK Dharma wanita Gresik merupakan salah satu sekolah menegah kejuruan yang siswanya didominasi dengan remaja putri, dan di SMK ini belum mempunyai kader kesehatan reproduksi .

Sehubungan dengan hal tersebut maka diperlukan suatu program yang mendukung tingkat perkembangan masa remaja selain memberikan pendidikan kesehatan reproduksi remaja perlu juga dilakukan Pembentukan Kader Kesehatan Remaja yang melibatkan sekolah. Kader Kesehatan Remaja adalah sekolah. Kader Kesehatan Remaja adalah peserta didik yang dipilih guru guna mengikuti dan melaksanakan sebagian usaha pelayanan kesehatan 
Diyana F.-Edukasi Kesehatan Reproduksi Remaja Putri Tentang Personal Hygiene Saat Menstruasi -hlm 15-20

terhadap diri sendiri, keluarga, teman peserta didik pada khususnya dan sekolah pada umumnya.

Untuk meningkatkan pengetahuan para konselor maka perlu dilakukan pendidikan kesehatan dan pembinaan bagi para anggota konselor teman sebaya di SMK Dharma Wanita Gresik.

\section{METODE}

Pengabdian masyarakat yang dilakukan di SMK Dharma Wanita Gresik ini menggunakan metode diskusi, penunjukan Kader dan penyuluhan melalui media sosial.

Berdiskusi dengan wakil kepala Sekolah SMK Dharma Wanita Gresik tentang permasalahan dan penanganan masalah yang dilanjutkan dengan penunjukan Kader Kesehatan Reproduksi Remaja oleh pihak sekolah.

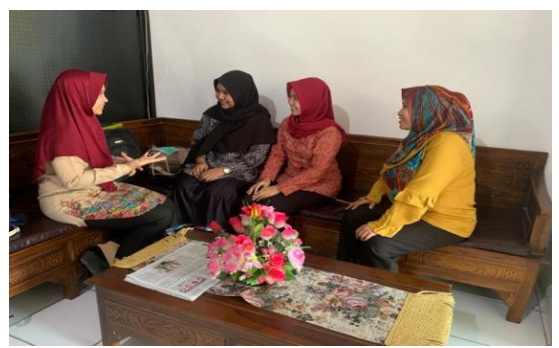

Gambar 1. Pelaksanaan diskusi dengan wakil kepala sekolah dan penunjukan KKR oleh pihak sekolah

Penyuluhan lewat media sosial menggunakan video tutorial tentang personal Hygiene saat menstruasi dan public speaking. Dan Mengadakan tanya jawab antara siswa dengan tim kami dari Fakultas Kesehatan Universitas Muhammadiyah Gresik melalui whatsapp (WA).

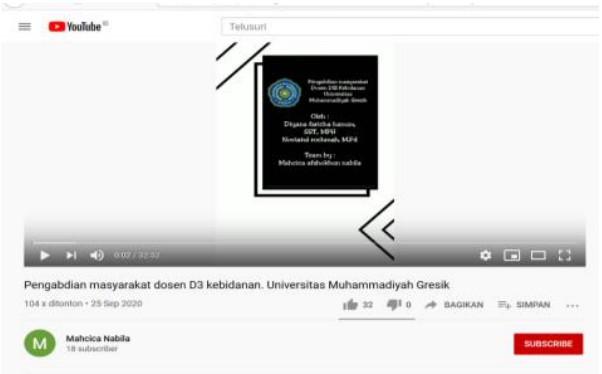

Gambar 2. Tampilan Chanel Youtube Untuk video tutorial tentang personal Hygiene saat menstruasi dan public speaking

\section{HASIL DAN PEMBAHASAN}

Hasil dari kegiatan pengabdian masyarakat ini adalah diperoleh 10 kader kesehatan remaja putri yang ditunjuk oleh wakil kepala sekolah, proses kegiatan dimulai dengan pre test, dilanjut dengan pemberian video tutorial penyuluhan personal Hygiene saat menstruasi dan public speaking, dan diakhiri dengan sesi Post test terhadap kader.

Adapun hasil dari pre test, post test, dan tabel silang perubahan pengetahuan siswa sebelum dan sesudah diberikan penyuluhan dijelaskan pada tabel berikut:

Tabel 1. Hasil Pre Test Pengetahuan Kesehatan reproduksi Remaja tentang personal hygine saat menstruasi dan Publik speaking

\begin{tabular}{lcc}
\hline \multicolumn{1}{c}{ Pengetahuan } & $\mathrm{N}$ & $\%$ \\
\hline Kurang & 5 & 50 \\
\hline cukup & 2 & 20 \\
\hline Baik & 3 & 30 \\
\hline Total & 10 & 100 \\
\hline
\end{tabular}

Dari tabel tersebut menunjukkan bahwa sebagian besar siswi yang ditunjuk sebagai kader berpengetahuan kurang tentang kesehatan reproduksi remaja putri tetntang personal hygine saat menstruasi dan publik speaking, yaitu sebanyak 5 siswi (50\%), dan yang berpengetahuan baik hanya 3 siswi (30\%).

Tabel 2. Hasil Post Test Pengetahuan kesehatan reproduksi remaja tentang personal hygine saat menstruasi dan publik speaking

\begin{tabular}{lcc}
\hline Pengetahuan & N & $\%$ \\
\hline Kurang & 1 & 10 \\
\hline Cukup & 4 & 40 \\
\hline Baik & 5 & 50 \\
\hline Total & 10 & 100 \\
\hline
\end{tabular}

Dari tabel tersebut menunjukkan bahwa pengetahuan siswa setelah dilakukan penyuluhan tentang kesehatan reproduksi remaja putri tentang personal hygine saat menstruasi dan publik speaking, pengetahua siswi/kader ada peningkatan yaitu sebanyak 5 siswi (50\%) dan yang berpengetahuan kurang hanya 1 siswi (10\%).

Berdasarkan tabel 3 didapatkan hasil terjadi penurunan jumlah pengetahuan kurang dari 5 siswi (50\%) menjadi 1 siswi (10\%), dan didapatkan hasil terjadi peningkatan untuk siswi 
berpengetahuan baik dari 3 siswi (30\%) menjadi 5 siswi (50\%).

Tabel 3. Hasil pengetahuan kesehatan reproduksi remaja tentang personal hygine saat menstruasi dan publik speaking siswa sebelum dan sesudah diberikan penyuluhan.

\begin{tabular}{lcccc}
\hline Pengetahuan & Pre & $\%$ & Post & $\%$ \\
\hline Kurang & 5 & 50 & 1 & 10 \\
\hline Cukup & 2 & 20 & 4 & 40 \\
\hline Baik & 3 & 30 & 5 & 50 \\
\hline Total & 10 & 100 & 10 & 100 \\
\hline
\end{tabular}

\section{Pembahasan}

1. Materi Kesehatan Reproduksi Remaja Putri Tentang Personal Hygiene Saat Menstruasi

Kesehatan reproduksi adalah keadaan sejahtera fisik, mental dan sosial yang utuh dalam segala hal yang berkaitan dengan fungsi, peran dan system reproduksi (Konferensi International Kependudukan dan Pembangunan, 1994).

Kesehatan reproduksi remaja adalah suatu kondisi sehat yang menyangkut sistem, fungsi dan proses reproduksi yang dimiliki oleh remaja. Pengertian sehat disini tidak semata-mata berarti bebas penyakit atau bebas dari kecacatan namun juga sehat secara mental serta sosial kultural. Remaja perlu mengetahui kesehatan reproduksi agar memiliki informasi yang benar mengenai proses reproduksi serta berbagai faktor yang berhubungan. Dengan informasi yang benar, diharapkan remaja memiliki sikap dan tingkah laku yang bertanggung jawab mengenai proses reproduksi [8].

Pentingnya menjaga kesehatan reproduksi bagi remaja karena masa remaja adalah waktu terbaik untuk membangun kebiasaan baik menjaga kebersihan, yang bisa menjadi aset dalam jangka panjang.

Remaja putri termasuk kategori kelompok yang lebih berisiko tinggi terkena Infeksi Saluran Reproduksi (ISR). ISR yang berlanjut dapat mengakibatkan kemandulan hingga terjadi kehamilan di luar kandungan. Penyebab ISR adalah salah satunya perilaku personal hygiene yang kurang benar.

Menurut Yuni (2015), Hygiene pada saat menstruasi memegang peranan penting dalam status kesehatan seseorang, termasuk menghindari adanya gangguan pada fungsi alat reproduksi. Pada saat menstruasi,pembuluh darah dalam rahim sangat mudah terinfeksi, oleh karena itu kebersihan alat kelamin harus lebih dijaga karena kuman mudah sekali masuk dan dapat menimbulkan penyakit pada saluran reproduksi [9].

Personal Hygiene yang bisa dilakukan saat menstruasi yaitu: Cuci Tangan, cara cebok yang benar, ganti pembalut, ganti celana dalam dan pemilihan pembalut yang benar.

\section{Pemberian Penyuluhan Tentang Personal Hygine Saat Mentruasi}

Kami tim dari Fakultas Kesehatan Universitas Muhammadiyah Gresik mengadakan pengabdian masyarakat di SMK Dharma Wanita Gresik, dengan tujuan memperbaiki situasi dan kondisi yang menjadi hambatan bagi guru dan siswa dilingkungan sekolah. Dimana dalam proses belajar mengajar atau dilingkungan sekolah siswa mengalami keluhan bingung jika menginginkan konsultasi tentang kesehatan reproduksi dan masih belum tahu apa pentingnya personaal hygine saat menstruasi untuk kesehatan reproduksinya. Beberapa faktor yang dapat menyebabkan masalah kesehatan reproduksi pada remaja antara lain kurangnya pengetahuan/informasi, gaya hidup, kurangnya menjaga personal hygine.

Perlunya diadakan promosi kesehatan kepada remaja putri dengan cara memberikan penyuluhan tentang kesehatan reproduksi khususnya tentang personal hygiene serta diperlukan dukungan dari semua pihak khususnya pihak sekolah dan keluarga dalam penerapan personal hygiene yang baik dan benar sehingga infeksi pada organ reproduksi dapat dicegah [10].

Untuk itu tim kami memberikan solusi untuk pemecahan masalah yang dialami ini dengan membentuk kader kesehatan reproduksi dan memberikan penyuluhan sehingga para siswa yang ditunjuk sebagai kader bisa menjadi konselor untuk teman sebayanya.

Dimana pada perencanaan awal penyuluhan ini akan kita berikan secara langsung kepada kader kesehatan reproduksi. Tapi harapan kami tidak terlaksana dengan baik karena ada kondisi dimana siswi tidak bisa masuk sekolah dikarenakan ada wabah pandemi covid-19 yang terjadi saat ini.

Akan tetapi kami tetap berusaha keras untuk mewujudkan harapan kami memberikan penyuluhan dengan cara menggunakan media sosial. Media sosial yang kami gunakan adalah youtube dan whatsapp. Dimana materi yang kita berikan adalah tentang personal hygine saat menstruasi dan public speaking yang bisa disimak dan disaksikan pada link video: https://youtu.be/FZuNTxH8GrQ 
Di link video atau youtube yang ada diatas, siswa menyimak dengan baik, sehingga siswa memahami apa yang harus dilakukan saat mentruasi dan cara berkomunikasi sebagai konselor untuk teman sebayanya. Penyuluhan ini kita cek pada tanggal 26 Agustsu 2020, hasil yang kami dapatkan yaitu sebanyak 103 viewers, 32 like dan subcriber yang berjumlah 18 orang. Kami merasa bangga karena kegiatan ini ada yang menyukai dan bermanfaat untuk kita semua, terkhusus untuk para remaja putri yang belum paham tentang pentingnya personal hygine saat mentruasi untuk kesehatan reproduksinya.

3. Pengetahuan remaja putri tentang personal hygine saat menstruasi setelah diberikan penyuluhan.

Sebelum diberikan penyuluhan, kami selaku tim pengabdian melakukan pre test terlebih dahulu guna untuk mengetahui sejauh mana pengetahuan mereka tentang kesehatan reproduksi remaja putri tentang personal hygine saat menstruasi dan public speaking, dan hasilnya dari 10 calon kader kesehatan reproduksi yang memiliki pengetahuan kurang sebanyak 5 siswi $(50 \%)$ sedangkan yang memiliki pengetahuan baik hanya 3 siswi (30\%). Namun setelah kami memberikan penyuluhan melalui link video atau youtube dengan materi kesehatan reproduksi remaja putri tentang personal hygine saat menstruasi dan pelatihan public speaking. Kemudian kami melakukan post test membuahkan hasil perubahan yang sangat baik, dimana didapatkan hasil terjadi penurunan jumlah pengetahuan kurang dari 5 siswi (50\%) menjadi 1 siswi (10\%), dan didapatkan hasil dimana terjadi peningkatan untuk siswi berpengetahuan baik dari 3 siswi (30\%) menjadi 5 siswi (50\%).

Hal ini menunjukkan bahwa siswi dapat memahami materi yang telah disampaikan oleh narasumber. Dan hasil ini sejalan dengan hasil kegiatan pengabdian yang telah dilakukan oleh Wismaningsih (2017) yang menunjukkan hasil bahwa promosi kesehatan dapat meningkatkan pengetahuan remaja dalam memahami higine menstruasi yang baik sebagai upaya meningkatkan kesehatan reproduksi pada remaja serta dapat diaplikasikan dalam kehidupan sehari-hari.

\section{KESIMPULAN}

Kegiatan pengabdian masyarakat telah dilakukan di SMK Dharma Wanita Gresik dibagi menjadi 4 sesi yakni: Pembentukan Kader kesehatan Remaja, pre test, penyuluhan kesehatan reproduksi remaja putri tentang personal hygine saat menstruasi dan pelatihan public speaking melalui media sosial, dan Post tes.

Setelah dilakukan penyuluhan, hasil yang kami harapkan yaitu pengetahuan dan cara berkomunikasi konselor tentang personal hygine saat menstruasi jauh lebih baik dari sebelumnya. Dan hasil dari kegiatan pengabdian ini sudah sesuai dengan harapan kami.

Dan pada akhir kegiatan pengabdian masyarakat ini diharapkan kader kesehatan remaja yang telah dilatih bisa menjadi konselor kesehatan reproduksi remaja yang baik bagi teman sebayanya dalam lingkup satu sekolah, dan diaplikasikan dalam kehidupan sehari-hari sehingga meminimalisir masalah yang dapat terjadi pada kesehatan reproduksi remaja.

\section{SARAN}

Diharapakan siswi yang telah ditunjuk sebagai kader kesehatan remaja dapat menyampaikan pengetahuan/informasi yang sudah didapat, dan menjadi konselor yang baik untuk teman sebayanya dalam lingkup satu sekolah.

\section{DAFTAR PUSTAKA}

1. Anugrahadu, S. 2019. Mengenal Remaja Generasi Z. http://ntb.bkkbn.go.id/?p=1467

2. BKKBN, 2013. Bimbingan Teknis Kesehaan Reproduksi dan Seksualitas yang Komprehensif. Jakarta: BKKBN

3. Potter, Perry. 2010. Fundamental Of Nursing: Consep, Proses and Practice.Edisi 7. Vol. 3. Jakarta : EGC

4. Phytagoras, K.C. 2017. Personal Hygiene Putri Ketika Menstruasi. Jurnal Promkes, Vol.5, No 1 Juli 2017:12-24

5. Purba, E.I, Sitorus. MEJ, Masdalina Pane. M. 2020. Upaya Pemberdayaan Siswa Untuk Meningkatkan Kesehatan Reproduksi Di MTs Khoirotulislamiah Pematang Siantar. Jurnal Abdimas Mutiara. Volume 1, Nomor : 1, Maret 2020

6. Wismaningsih, ER. Ratna F. Nur Khalim, dan Krisnita D. Jayanti. 2017. Sehat dan Bersih Meski Sedang Haid di SDN 1 Kedak Desa KedakKabupaten Kediri. Prosiding Seminar Pengabdian Masyarakat Institut Ilmu Kesehatan Bhakti Wiyata Kediri. Hal 69-74 
Diyana F.-Edukasi Kesehatan Reproduksi Remaja Putri Tentang Personal Hygiene Saat Menstruasi -hlm 15-20

7. Kementrian Kesehatan RI, 2015. Infodatin Pusat Data dan Informasi Kesehatan Reproduksi Remaja. Jakarta

8. Adjie, J. M. S . 2013. Kesehatan Reproduksi Remaja dalam Aspek Sosial. https://www.idai.or.id/artikel/seputarkesehatan-anak/kesehatan-reproduksiremaja-dalam-aspek-sosial.

9. Yuni, N.E. 2015. Buku saku personal hygiene.Yogyakarta :Nuha Medika.

10. Suryani, L. 2019. Faktor-faktor Yang Mempengaruhi Perilaku Remaja Putri Tentang Personal Hygiene Pada Saat Menstruasi Di SMP Negeri 12 Kota Pekanbaru. JOMIS (Journal Of Midwifery Science). Vol 3. No.2, Juli 2019 